\title{
Changes in Holocene meridional circulation and poleward Atlantic flow: the Bay of Biscay as a nodal point
}

\author{
Yannick Mary $^{1}$, Frédérique Eynaud ${ }^{1}$, Christophe Colin $^{2}$, Linda Rossignol $^{1}, \operatorname{Sandra~Brocheray~}^{1, \mathrm{a}}$, Meryem Mojtahid ${ }^{3}$, \\ Jennifer Garcia ${ }^{3}$, Marion Peral ${ }^{1, b}$, Hélène Howa ${ }^{3}$, Sébastien Zaragosi ${ }^{1}$, and Michel Cremer ${ }^{1}$ \\ ${ }^{1}$ Laboratoire Environnements et Paléoenvironnements Océaniques et Continentaux (EPOC), UMR 5805, \\ Université de Bordeaux, 33615 Pessac, France \\ ${ }^{2}$ Laboratoire Géosciences, Université de Paris-Sud, 91405 Orsay CEDEX, France \\ ${ }^{3}$ UMR CNRS6112 LPG-BIAF, Recent and Fossil Bio-Indicators, Angers University, 2 Bd Lavoisier, \\ 49045 Angers CEDEX 01, France \\ anow at: Institut Polytechnique LaSalle-Beauvais, Dpt Géosciences, 19 rue Pierre Waguet, BP 30313, \\ 60026 Beauvais, France \\ b now at: Laboratoire des Sciences du Climat et de l'Environnement (LSCE-IPSL), Domaine du CNRS, bât.12, \\ 91198 Gif-sur-Yvette, France
}

Correspondence to: Yannick Mary (pelagos@hotmail.fr) and Frédérique Eynaud (frederique.eynaud@u-bordeaux.fr)

Received: 8 March 2016 - Discussion started: 25 April 2016

Revised: 22 December 2016 - Accepted: 10 February 2017 - Published: 9 March 2017

\begin{abstract}
This paper documents the evolution over the last $10 \mathrm{kyr}$ of one of the key parameters of climate: sea-surface temperatures (SSTs) in the North Atlantic. We focus on the southern Bay of Biscay, a highly sensitive oceanographic area regarding the dynamics of the North Atlantic subpolar and subtropical gyres (SPG and STG respectively). This site furthermore offers unique sedimentary environments characterized by exceptional accumulation rates, enabling the study of Holocene archives at (infra)centennial scales. Our results mainly derive from planktonic foraminiferal association analysis on two cores from the southern Landes Plateau. These associations are used as the basis of modern analogue technique transfer functions to track past hydrographical changes. SST reconstructions were thus obtained at an exceptional resolution and compared to a compilation of Holocene records from the northeastern North Atlantic. From this regional perspective are shown fundamental timing differences between the gyre dynamics, nuancing classical views of a simple meridional overturning cell. Our study highlights that western Europe underwent significant oscillations of (annual) SST during the last $10 \mathrm{kyr}$. During well-known intervals of mild boreal climate, warm shifts of more than $3{ }^{\circ} \mathrm{C}$ per century are accurately concomitant with positive sea-surface temperature anomalies and rise of mi-
\end{abstract}

cropalaeontological indicators of gyre dynamics in the northern North Atlantic, pointing to periods of greater intensity of the North Atlantic Current (SPG cell especially). Conversely, the SST signal records short-term cold anomalies which could be related to weaker SPG dynamics.

\section{Introduction}

The Atlantic Meridional Overturning Circulation (AMOC) and its dynamics are critical regarding the modulations of climate (amplitude and frequency) over Europe (westerlies, droughts and/or stormy periods, e.g. Clark et al., 2002; Bryden et al., 2005; Dawson et al., 2004; Magny et al., 2003; Sorrel et al., 2009; Trouet et al., 2012; Van Vliet-Lanoe et al., 2014a, b; Jackson et al., 2015). The two connected North Atlantic gyres, the subpolar gyre (SPG) and the subtropical gyre (STG) are fundamental for these processes as they transfer heat and salt toward the Nordic seas (e.g. McCartney and Mauritzen, 2001; Pérez-Brunius et al., 2004; Hatun et al., 2005; Morley et al., 2014) where convection occurs (e.g. Lozier and Stewart, 2008). Their expansions and contractions notably control the inflow from the North Atlantic Current (NAC) to higher latitudes, thus also affecting the heat 
budget of the Greenland-Iceland-Norwegian seas, which is critical in the meridional climatic balance (e.g. Hatun et al., 2005). During the late Holocene, changes in the STG and SPG dynamics contributed to well-known climatic anomalies in western Europe, such as the Little Ice Age or the Medieval Warm Period/Anomaly, and probably played a major role at longer timescales (Thornalley et al., 2009; Colin et al., 2010; Copard et al., 2012; Sorrel et al., 2012; Staines-Urías et al., 2013; Morley et al., 2014).

By providing the first Holocene inventory of (infra)centennial hydrographic changes in the inner Bay of Biscay, this paper aims at testing European temperate oceanic signals vs. those from a broader North Atlantic view with a focus on the SPG dynamics. Our study site (Fig. 1) is ideally located under the temperate eastern limb of the NAC, in the southern Bay of Biscay and not far from the STG/SPG divergence zone (e.g. Planque et al., 2003). This geographic configuration provides to this marine environment a high sensitivity regarding Northern Hemisphere climatic signals at present (e.g. Le Cann and Serpette, 2009; Esnaola et al., 2013; Garcia-Soto and Pingree, 2012), echoing pan-Atlantic hydrographical changes, somewhat with amplified responses. Actually, the southern Bay of Biscay records at present the warmest SST (especially in summer) of the mid-latitude temperate band of the North Atlantic with a significant warming trend over the last decades (e.g. Koutsikopoulos et al., 1998; Valencia et al., 2003; deCastro et al., 2009; see also maps at http://www.nodc.noaa.gov/ cgi-bin/OC5/woa13fv2/woa13fv2.pl?parameter=t). Previous works done on sedimentary archives in the same area have furthermore evidenced a strong potential to track down the Holocene variability (Mojtahid et al., 2013; Garcia et al., 2013; Brocheray et al., 2014; Mary et al., 2015).

Today, the Bay of Biscay is characterized by a complex, variable sea-surface circulation with strong seasonal changes, marked by a September-October versus MarchApril SOMA pattern (e.g. Pingree and Le Cann, 1990; Pingree and Garcia-Soto, 2014). The main surface current in the Bay of Biscay is the European Slope Current (ESC), flowing northward along the Armorican Shelf (Fig. 1), with important spatial and seasonal variations (Garcia-Soto and Pingree, 2012; Charria et al., 2013). Circulation can reverse during summer along the shelf break, flowing weakly southwestward (Charria et al., 2013). In autumn-winter, the northward flow reaches a maximum, especially when combining with southern intrusions from the Iberian Poleward Current (IPC) which flows along the western Iberian margin (e.g. Peliz et al., 2005) before turning eastward at Cape Finisterre (NW Spain). The IPC northward extension into the Bay of Biscay is known as the Navidad Current (e.g. Garcia-Soto et al., 2002; Le Cann and Serpette, 2009). The winter mixing of the IPC and ESC is designated as the European Poleward Current (EPC, Garcia-Soto and Pingree, 2012), and drives relatively warm and saline water to the Nordic seas, contributing to their heat and salt budget. The Bay of Biscay is addition- ally strongly marked by surface water inflow coming from the North Atlantic Current (Fig. 1), which enters the Bay from its northwestern boundary (Pingree, 2005; Pingree and Garcia-Soto, 2014; Ollitrault and Colin de Verdière, 2014). In contrast with surface circulation of the inner Bay of Biscay, the NAC water inflow shows only limited seasonal variability. At inter-annual timescales however, NAC oscillations are mainly driven by westerly wind regime (Pingree, 2005), and consequently by the North Atlantic Oscillation (NAO), one of the key modes of climatic variability in the North Atlantic. So far, little is known about long-term oscillations of the NAC inflow into the Bay. Modern surveys of SST variability over the last 150 years in the Bay of Biscay report that temperature oscillations are mainly controlled by the Atlantic Multi-decadal Oscillation (AMO; Garcia-Soto and Pingree, 2012). The influence of the NAO on SST in the Bay of Biscay is more complex and contributes only little to the observed long-term trend, although sharp, inter-annual changes of the NAO index impact annual SST variability (Garcia-Soto and Pingree, 2012, Fig. 1c). Moreover, NAO conditions influence large-scale oceanic circulation patterns indirectly responsible for surface temperature anomalies over the Bay (Pingree, 2005; Garcia-Soto and Pingree, 2012; see also the synthesis within Mary et al., 2015).

The present paper is based on analyses conducted on two high-resolution well-dated cores from the southern part of the inner Bay of Biscay (Fig. 1, Table 1): core KS10b (e.g. Mojtahid et al., 2013) and core PP10-07 (e.g. Brocheray et al., 2014). These cores show exceptionally high sedimentation rates for the Holocene, up to $200 \mathrm{~cm} \mathrm{kyr}^{-1}$ for core PP10-07, and $86 \mathrm{~cm} \mathrm{kyr}^{-1}$ for core KS10b (see detailed description of these archives and of their sedimentological context in the respective references). Here we present past Holocene SST data reconstructed after an ecological transfer function based on the modern analogue technique (see Sect. 2, Methods) applied to planktonic foraminiferal assemblages. These Bay of Biscay sea-surface reconstructions are compared to selected North Atlantic Holocene records using a data mining exercise (referencing sea-surface reconstructions of high time-resolution) done in the frame of the French ANR HAMOC (Holocene North Atlantic Gyres and Mediterranean Overturning dynamic through Climate Changes) project database (see http://hamoc-interne.epoc. u-bordeaux1.fr/doku.php?id=start) .

\section{Methods}

\subsection{Age models}

Updated age models have been built for the Bay of Biscay cores. All raw ${ }^{14} \mathrm{C}$ ages were calibrated and converted to calendar ages using the Marine 13 calibration curve and the recommended age reservoir of 405 years (Reimer et al., 2013), as no adequate and robust local age reservoir values exist in the area (see Mary et al., 2015, for a discus- 


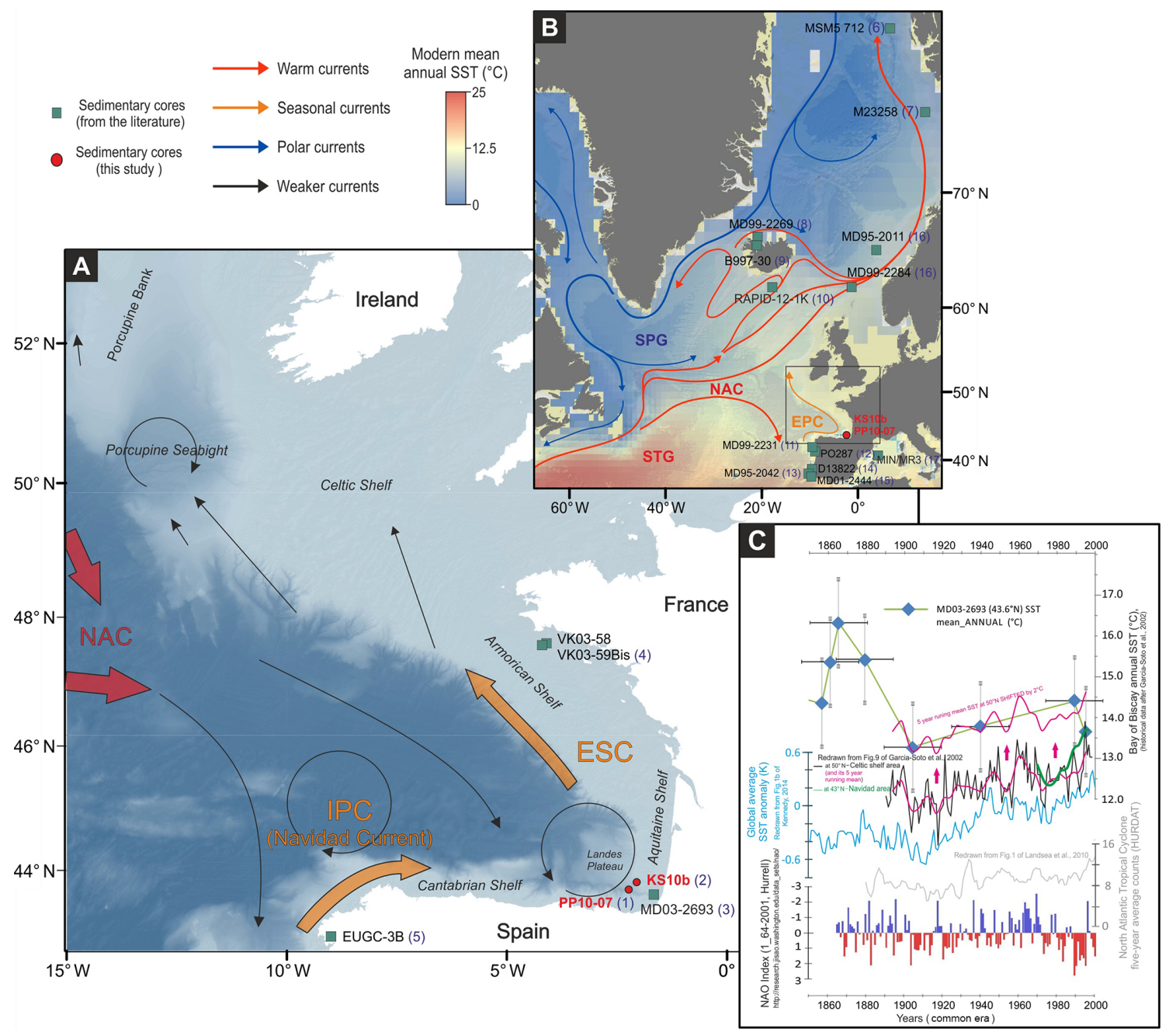

Figure 1. (a) Map showing the regional scheme of the main surface currents in the Bay of Biscay, drawn after the compilation of modern hydrological survey from Pingree and Garcia-Soto (2014). North Atlantic Current (NAC), Iberian Poleward Current (IPC), and European Slope Current (ESC) are respectively represented by the red and orange arrows. The studied sedimentary cores PP10-07 and KS10b from the inner Bay of Biscay are shown in red. Bathymetry from EMODNET. Additional Holocene records cited in the text are displayed by green squares. (b) North Atlantic general circulation pattern (SPG, subpolar gyre; STG, subtropical gyre; EPC, European Poleward Current; after Lherminier and Thierry, 2015) with the location of the northern and southern sedimentary records discussed in the text. Core references: (1) Brocheray et al. (2014); (2) Mojtahid et al. (2013); (3) - Gaudin et al. (2006), Mary et al. (2015); (4) Naughton et al. (2007a); (5) Pena et al. (2010); (6) Werner et al. (2013); (7) Sarnthein et al. (2003); (8) Giraudeau et al. (2004); (9) Andrews and Giraudeau (2003); (10) Thornalley et al. (2009); (11) Naughton et al. (2007b); (12) Abrantes et al. (2011); (13) Chabaud et al. (2014); (14) Rodrigues et al. (2009); (15) Martrat et al. (2007); (16) Risebrobakken et al. (2011); (17) Cisneros et al. (2016). (c) SST evolution over the last centuries in the Bay of Biscay (from the MD03-2693 sedimentological record and from the compilation of Garcia-Soto et al., 2002) and comparison, from top to bottom with the Global SST anomaly (after Kennedy, 2014), the Atlantic Tropical Cyclone Counts (after Landsea et al., 2010) and the NAO index of Hurell (http://research.jisao.washington.edu/data_sets/nao/).

sion). Smooth-spline regression based on the published ${ }^{14} \mathrm{C}$ dates ( $n=12$ for core Ks10b, Mojtahid et al., 2013) were applied (Fig. 2). For core PP10-07, two supplementary ${ }^{14} \mathrm{C}$ dates were obtained at the top of the sequence (Table 2) and the age model was built using a $5^{\circ}$ polynomial regression (Fig. 2). The core MD03-2693 age model (also exploited in this paper) was built using linear interpolation based on published ${ }^{14} \mathrm{C}$ and ${ }^{210} \mathrm{~Pb}(n=3$ and $n=8$, respectively, Mary et al., 2015). Age-depth modelling and calibration were performed using the dedicated software Clam (Blaauw, 2010), written in the open-source statistical environment R (http: //www.r-project.org/). 
Table 1. Location and references of the southern Bay of Biscay cores used in this study.

\begin{tabular}{lrrrrl}
\hline Cruise, Core label & $\begin{array}{r}\text { Latitude } \\
\left({ }^{\circ} \mathrm{N}\right)\end{array}$ & $\begin{array}{r}\text { Longitude } \\
\left({ }^{\circ} \mathrm{E}\right)\end{array}$ & $\begin{array}{r}\text { Water depth } \\
(\mathrm{m})\end{array}$ & $\begin{array}{r}\text { Longitudinal } \\
\text { distance }(\mathrm{km}) \\
\text { from the shore }\end{array}$ & $\begin{array}{l}\text { Data sources } \\
\text { and references }\end{array}$ \\
\hline SARGASS, PP10-07 & 43.677 & -2.228 & 1472 & 58 & This work, Brocheray et al. (2014) \\
PROSECAN IV, KS10b & 43.833 & -2.050 & 550 & 50 & This work, Mojtahid et al. (2013) \\
SEDICAR/PICABIA, MD03-2693 & 43.654 & -1.663 & 431 & 15 & This work, Gaudin et al. (2006), \\
& & & & Mary et al. (2015) \\
\hline
\end{tabular}
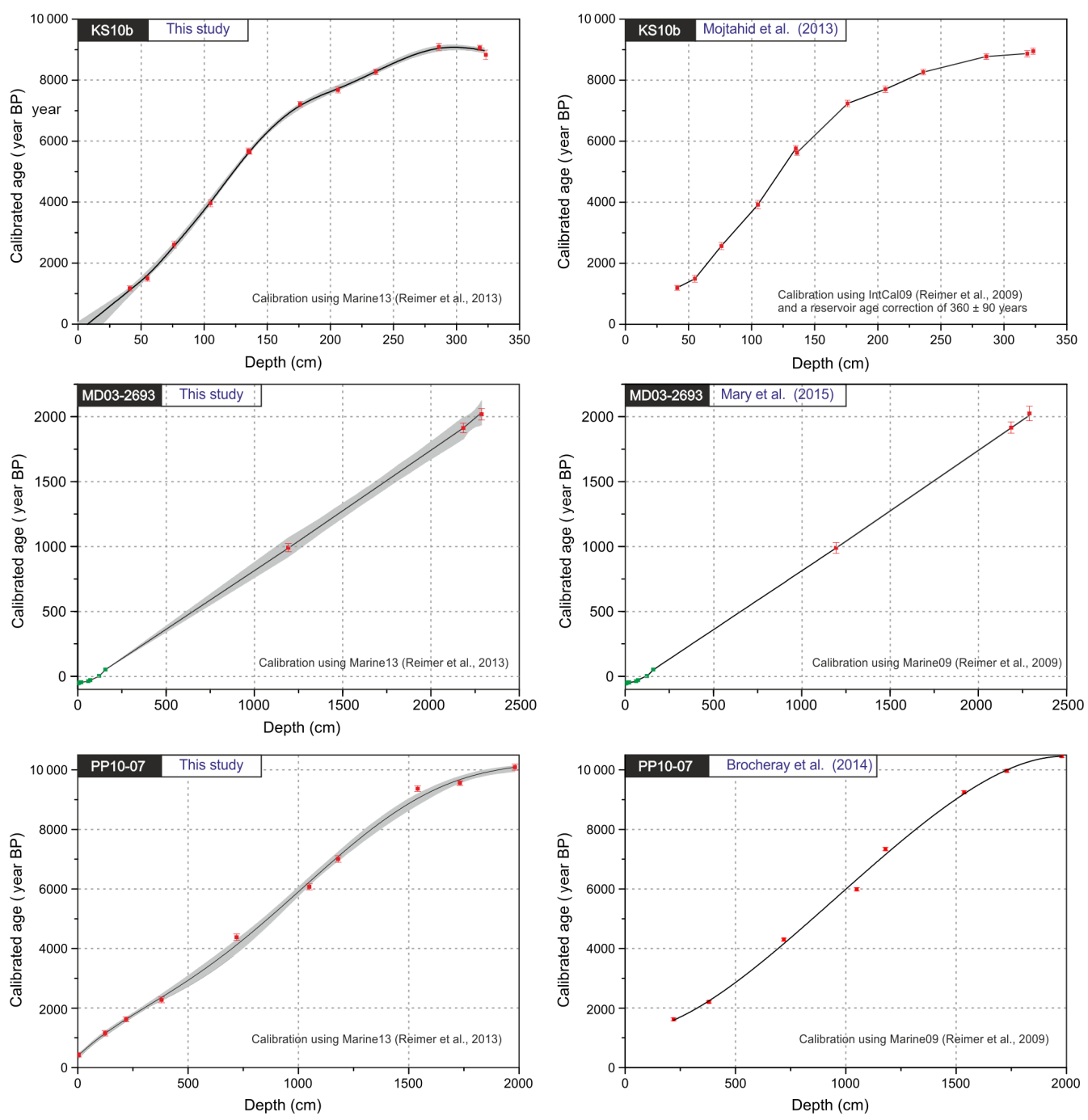

포 ${ }^{14} \mathrm{C}$ datings $( \pm 1 \sigma) \quad$ - ${ }^{210} \mathrm{~Pb}$ datings Confidence interval

Figure 2. Revised age models for cores KS10b, MD03-2693 and PP10-07 (left panels) compared to previous published age models (right panels with original references).

\subsection{Past hydrographical parameter quantification}

Planktonic foraminifera (PF) assemblages were used to quantify sea-surface parameters: species abundances were determined (counts of 300 specimens at least) on the
$>150 \mu \mathrm{m}$ fraction from sedimentary aliquots retrieved at maximum $10 \mathrm{~cm}$ intervals along the studied cores, thus giving a mean time resolution of 50 and 150 years for cores PP10-07 and KS10b respectively (see Supplement for detailed data). SST reconstructions were calculated using the 


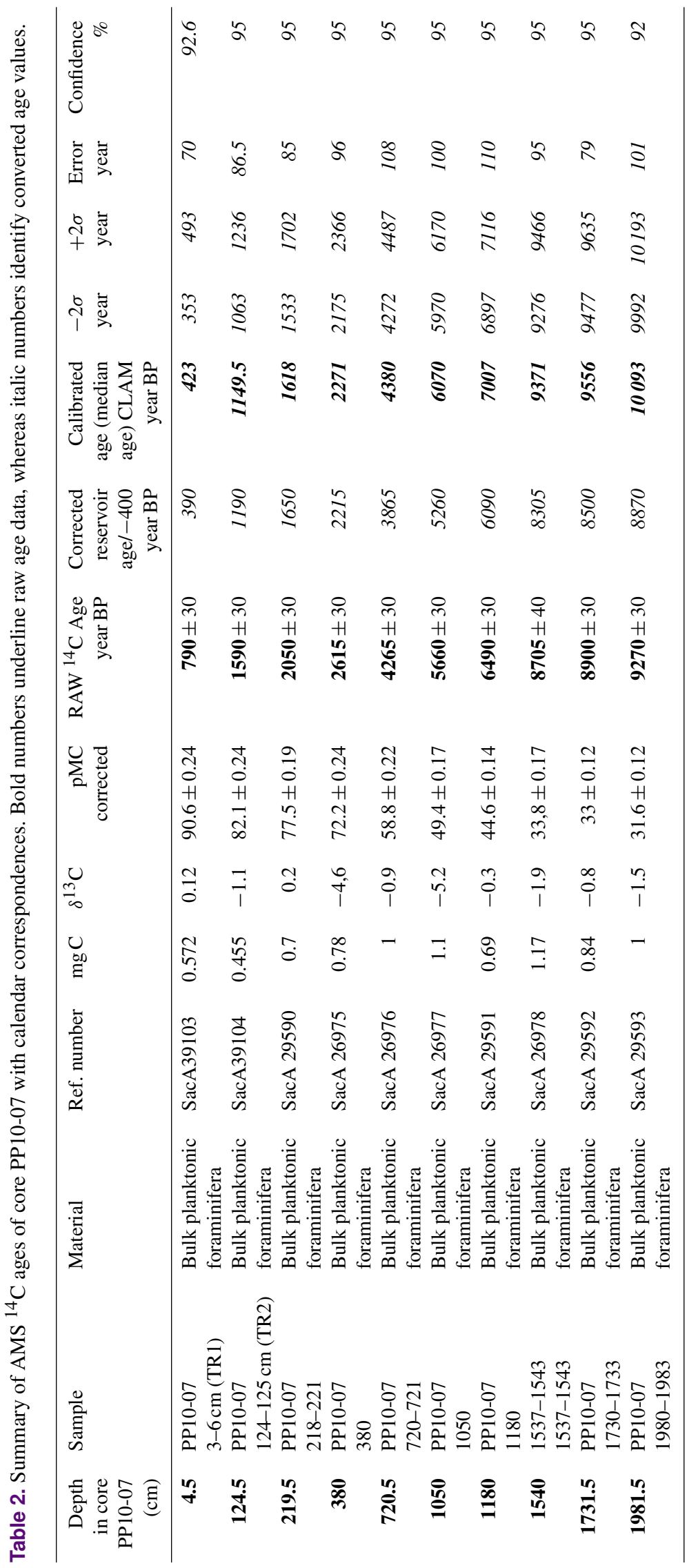


Modern analogue technique (MAT) a method successfully developed on PF (e.g. Pflaummann et al., 1996; Kucera et al., 2005; Telford and Birks, 2011; Guiot and de Vernal, 2007, 2011). The calculations derive from modern spectra previously compiled and tested separately in the frame of the MARGO exercise for the North Atlantic Ocean and the Mediterranean Sea respectively (Kucera et al., 2005; Hayes et al., 2005). They are based on sediment surface samples analysed for their contents in PF (specific relative abundances) and thus offer the advantage of already having integrated regional taphonomic processes. At EPOC (Environnements et Paléoenvironnements Océaniques et Continentaux) laboratory, these two MARGO databases were summed to provide larger analogue choices and ambiguous data points were excluded (i.e. non-stratigraphically constrained points showing anomalies in the biogeographical distribution), resulting in a final training set of $n=1007$ modern analogues. Modern sea-surface parameters were extracted from the WOA ATLAS with the sample tool developed by Schäfer-Neth and Manschke (2002). The latter was developed for the MARGO programme and interpolates the $10 \mathrm{~m}$ World Ocean Atlas WOA-1998 mean seasonal and mean annual temperatures over the four existing data points surrounding the sample location (see http://www.geo. uni-bremen.de/geomod/staff/csn/woasample.html) thus providing spatio-temporal averaged values of SST (see Kucera et al., 2005, for MARGO analytical developments and Telford et al., 2013, for further considerations).

Calculations were run under the $\mathrm{R}$ software with the BIOINDIC package (ReconstMAT script) developed by J. Guiot (https://www.eccorev.fr/spip.php?article389) using relative abundances of PF with no mathematical transformation (no logarithmic or square root transformations which are frequently used to increase the equitability within assemblages for instance; see Guiot and de Vernal, 2007, for a review).

Past hydrological parameter values are derived from a weighted average of the SST values of the five best analogues. The maximum weight is given for the closest analogue in terms of statistical distance (i.e. dissimilarity minimum). The ReconstMAT script furthermore includes the calculation of a threshold regarding this statistical distance which prevents calculation in the case of poor- or non-analogous situations. The degree of confidence of this method allows reconstruction of seasonal and annual SST with a maximum root mean square error of prediction (RMSEP) of $1.3^{\circ} \mathrm{C}$ (see Supplement). This method (named MATR_1007PF for modern analogue technique derived from 1007 modern spectra of PF assemblages) was extensively tested at EPOC including comparisons with similar MAT developed regionally on PF (e.g. Salgueiro et al., 2008, 2010) providing very coherent reconstructions along the western European margin (see Eynaud et al., 2013, for further details) and producing pertinent palaeoceanographical series (see Penaud et al., 2011; Sánchez Goñi et al., 2012, 2013, for records also produced with MATR_1007PF). Additionally, our work benefited from modern calibrations conducted on PF from the same area of the Bay of Biscay (i.e. Retailleau et al., 2009, 2012).

\section{Holocene SST oscillations in the Bay of Biscay}

Despite the different bathymetric and physiographic positions of the studied cores (Fig. 1, Table 1), reconstructed annual SST in the Bay of Biscay shows coherent oscillations of remarkably similar timing (Fig. 3a). Small amplitude differences are observed between the two studied records, but synchronous warm periods are clearly identified between 8.2 and 7.4 and between 6.6 and $5.6 \mathrm{kyr} \mathrm{BP}$, these intervals roughly corresponding to the upper and lower limits of the mid-Holocene hypsithermal in the North Atlantic region (e.g. Eynaud et al., 2004; Walker et al., 2012; Tanner et al., 2015).

On historical timescales, warm intervals are detected in both cores between 2.6 and $1.8 \mathrm{kyr}$ BP (Roman Warm Period, RWP) and between 1.2 and 0.5 kyr BP (Medieval Warm Period, MWP), although less obvious in core KS10b because of the lower time resolution. An offset of up to $4{ }^{\circ} \mathrm{C}$ above mean annual modern values is observed during a large temperature excursion around ca. $2 \mathrm{kyr}$ BP in core PP10-07 only. The amplitude of the warmings detected between 8.2 and 7.4 and between 6.6 and $5.6 \mathrm{kyr} \mathrm{BP}$ reaches 2 to $3{ }^{\circ} \mathrm{C}$ in both records. Such amplitudes in the detected SST warm pulses are especially high in comparison to modern annual values. However, considering the strong modern seasonal SST variations in the Bay of Biscay (as shown on Fig. 3a), a $4{ }^{\circ} \mathrm{C}$ shift of mean annual SST is coherent with a deviation of annual mean temperature toward mean summer values.

Comparison of the southern Bay of Biscay SST reconstructions with other records from the western European margin (Figs. 3, 4 and 5) suggests that the observed millennialscaled warm episodes are coherent features which reflect characteristic climatic patterns, at least expressed regionally, but also probably more broadly. Indeed, further along the Bay of Biscay margin, other high-resolution Holocene archives reveal similar and synchronous episodes (Fig. 3c). Concomitantly to the observed warm SST pulses also seen within the seasonal means (see Supplement), Holocene pollen assemblages from core VK03-58bis (pollen data not shown; Naughton et al., 2007a) indicate a decrease in mean annual precipitations; this drought being related, according to the authors, to a change in the seasonality with warmer summers especially. In the same way, the evolution of coccolithophorid concentrations in the subpolar North Atlantic along the Irminger Current pathway, interpreted as indicating stronger contribution of NAC water toward the Nordic seas (Andrews and Giraudeau, 2003; Giraudeau et al., 2004; Moros et al., 2012), showed strong similarities with the Bay of Biscay SST signals. Peaks in coccolithophorid abundances in cores B997-330 and MD99-2269 (Fig. 4e and f) (see location 


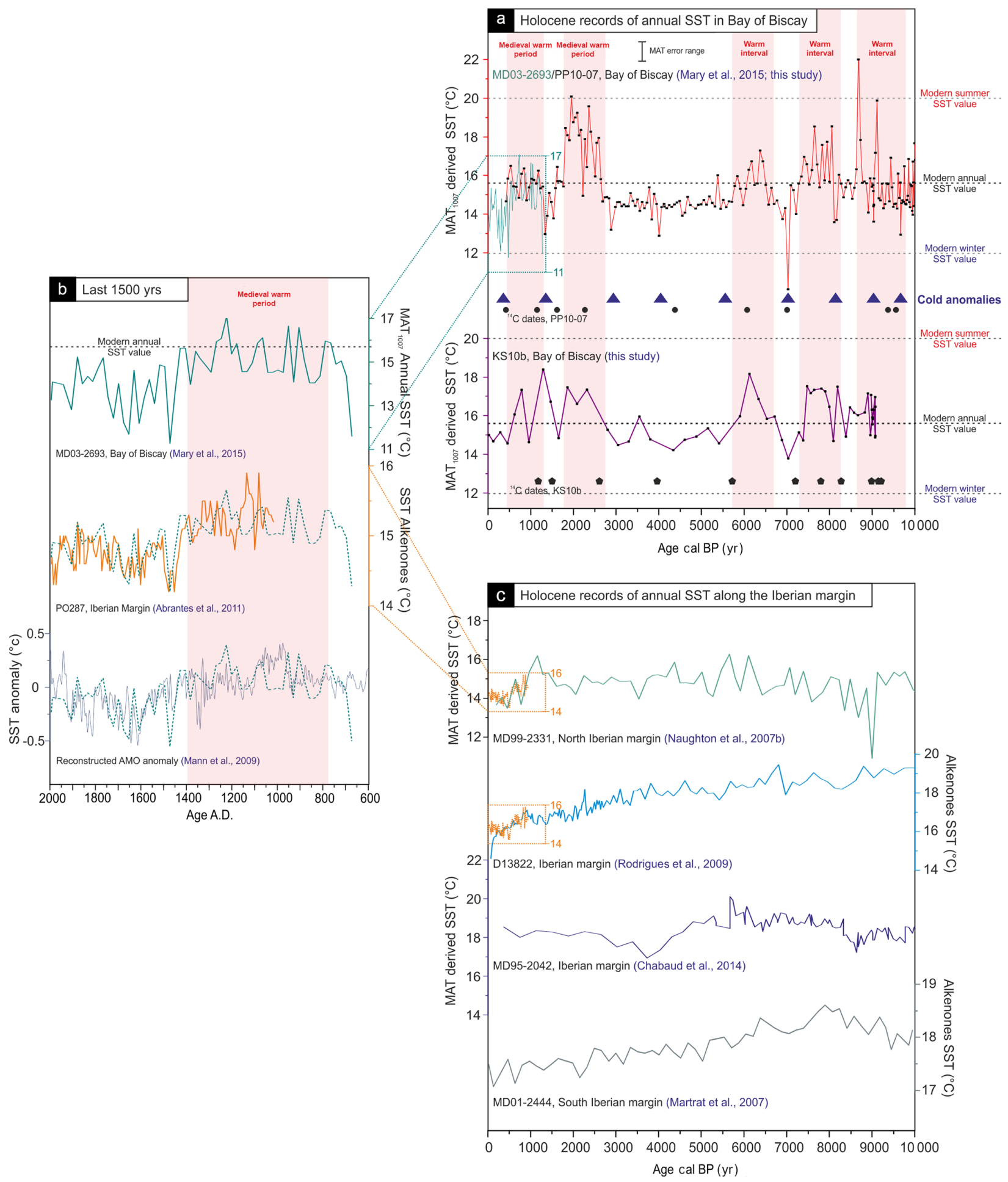

Figure 3. Mean annual sea surface temperature (SST) records from the western European margin. (a) Holocene SST signals from cores PP10-07 and KS10b (this study) reconstructed using the modern analogue technique (MAT) based on planktonic foraminifera (see Sect. 2, Methods), and compared to SST signal of the adjacent core MD03-2693 (Mary et al., 2015). Black dots identify ${ }^{14} \mathrm{C}$ age control points. (b) SST signals spanning the last 1500 years in the Bay of Biscay (core MD03-2693) based on MAT and from the Iberian margin (core PO287-06; Abrantes et al., 2011) using alkenones. Reconstructed signals are compared with the AMO reconstruction of Mann et al. (2009). The dotted curve represents core MD03-2693 signal transposed on top of the two other curves. (c) Holocene SST signals from the Iberian margin using MAT based on planktonic foraminifera for cores MD99-2331 (after Naughton et al., 2007b) and MD95-2042 (after Chabaud et al., 2014) and alkenones for cores D13882 (after Rodrigues et al., 2009) and MD01-2444 (after Martrat et al., 2007). 


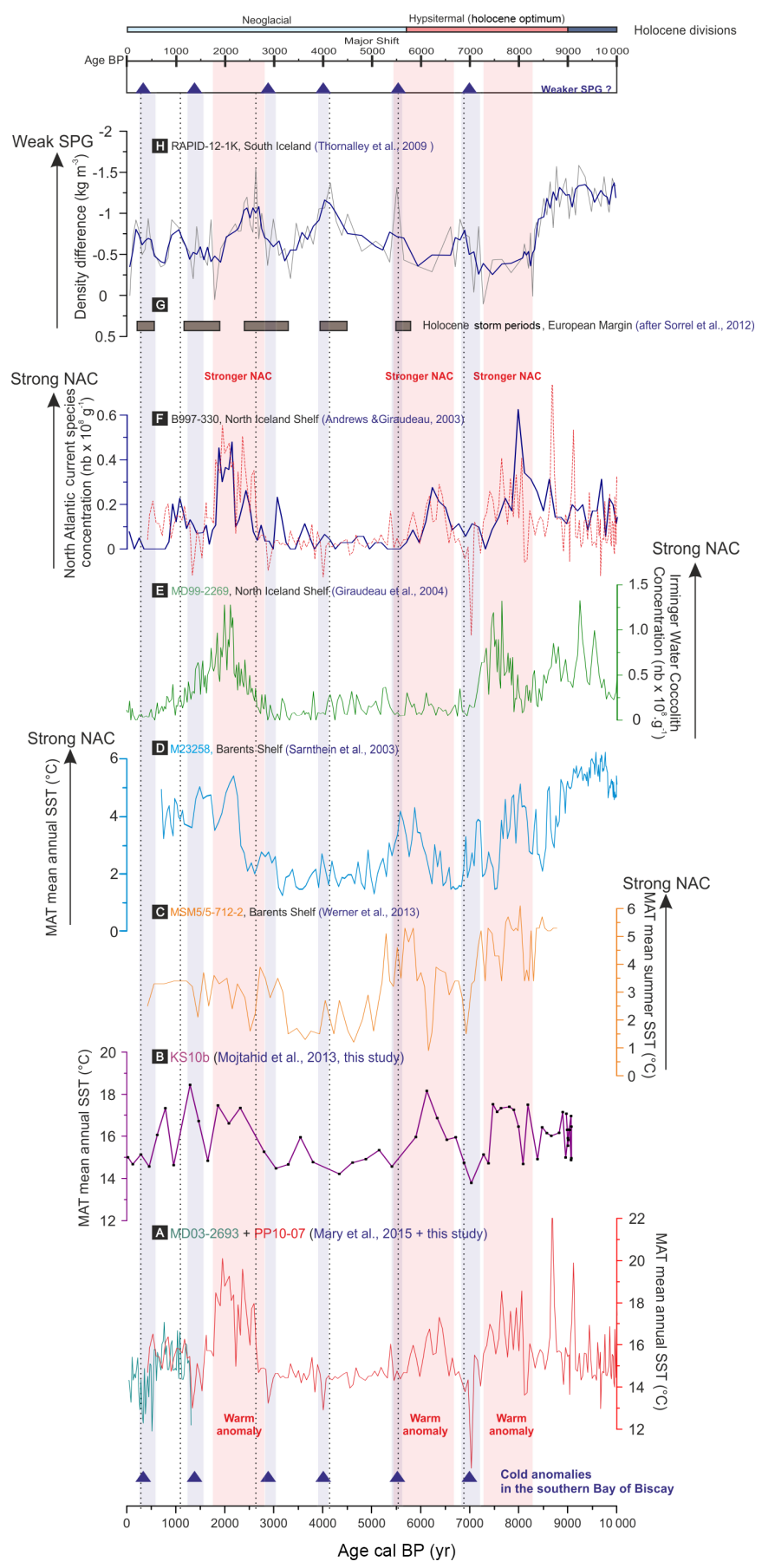

Figure 4. Comparison of annual SST Holocene signals from the Bay of Biscay (a, b) with records from the northern North Atlantic highlighting variations of the NAC intensity and SPG dynamics; (c) SST signal of core MSM5/5-712-2 (Fram Strait; Werner et al., 2013) and of (d) core M23258 (Barents Shelf, after Sarnthein et al., 2003), both reconstructed using the modern analogue technique (MAT) based on planktonic foraminifera; (e) concentration of NAC indicator coccolith species in core MD99-2269 (North Iceland Shelf, after Giraudeau et al., 2004) and in (f) core B997-330 (North Iceland Shelf, after Andrews and Giraudeau, 2003; the PP10-07 record here is also plotted by a thin dotted red line to underline the comparison); (g) Holocene storm periods (after Sorrel et al., 2012) reconstructed from sedimentological evidence from a compilation of coastal cores in northwestern Europe; and (h) core Rapid-12-1K (Thornalley et al., 2009) proxy for upper-water-column stratification, calculated using derived $\mathrm{Mg} / \mathrm{Ca}$ and $\delta^{18} \mathrm{O}$ temperatures and salinities of $G$. bulloides and G. inflata. Dotted vertical lines point out events of density difference between the near-surface and base of the seasonal thermocline in the southern Iceland Basin. The topmost dark blue triangles and light blue vertical bands point to cold anomalies recorded in the southern Bay of Biscay (potentially corresponding to a weak SPG). Pink bands conversely highlight periods of warmth which also correspond to enhanced NAC activity north of Iceland. Changes in gyre circulation dynamics are compared with the Holocene division of Wanner et al. (2008). 
on Fig. 1) were recorded synchronously to the warm pulses in the Bay of Biscay, with especially positively marked anomalies detected around 2 and $8 \mathrm{kyrBP}$. The Bay of Biscay SST oscillations further correspond with those reconstructed from marine records from the Barents Shelf (see location on Fig. 1) from core MSM5/5-712-2 (Werner et al., 2013, Fig. 3c) and core M23258 (Sarnthein et al., 2003; Fig. 3d). This coherency suggests teleconnections between the southern Bay of Biscay and the Nordic seas, probably due to a common driving mechanism linked to the NAC inflow vigour and its split between the SPG and the STG.

In between the observed warm intervals, SST reconstructions of core PP10-07 and KS10b reveal several low values slightly colder than today (Fig. 3a). The time interval between 5.6 and $2.6 \mathrm{kyr} \mathrm{BP}$ is characterized by temperatures around $-1{ }^{\circ} \mathrm{C}$ cooler compared to the modern ones. This period roughly corresponds to the late Holocene Neoglacial Cooling (e.g. Eynaud et al., 2004; Wanner et al., 2008; Walker et al., 2012). In the same way, short-lived events of $2{ }^{\circ} \mathrm{C}$ cooling are visible around ca. 8.2, 7, 5.5, 4, 2.9 and 1.7 kyr BP (Figs. 3 and 4). The three older anomalies are synchronous and well marked in both KS10b and PP10-07 cores.

The comparison of the timing of these cold spells to other existing Holocene reconstructions from the North Atlantic Ocean reveals that they represent coherent and reproducible features (Fig. 4). Interestingly, density anomalies thought to reflect millennial-scale variability in the SPG dynamics (Thornalley et al., 2009; Farmer et al., 2011) were recorded nearly synchronously (within the age model uncertainties) in the southern Iceland Basin (it is especially obvious before $4 \mathrm{ka}$ ). These anomalies were interpreted (i.e. Thornalley et al., 2009) as reflecting a strong/weak, longitudinally extended/contracted SPG thus driving more/less vigorous but fresher/saltier Atlantic inflow throughout the Faroe current branch and thus modulating the AMOC strength. The good temporal correspondence between the cold spells detected in core PP10-07 (even if shorter) and the density anomalies (core RAPiD-12-1K, Fig. 4h) registered in the subpolar North Atlantic support, as seen for warm events, a direct teleconnection with the inner Bay of Biscay, probably throughout a STG/SPG seesaw which would influence tracks/intensities of the temperate westerlies. The short-lived cold anomalies of PP10-07 are furthermore concomitant with periods of increased storminess identified in various coastal sediments from the NW European margin (Holocene storm periods after Sorrel et al., 2012, Fig. 3g). These periods have been related to a weakened, westward contracted SPG, involving a rapid feedback in the atmospheric dynamics (e.g. westerlies intensity and/or latitudinal migrations).

In the subtropical North Atlantic, study of benthic foraminiferal stable isotopes in core EUGC-3B (located in the Galician Shelf; Pena et al., 2010; see Fig. 1) also showed similar cold anomalies which were interpreted by the authors as suggesting enhanced contribution of colder, eastern North
Atlantic Central waters (ENACW) reaching the Iberian margin during these events.

\section{The European poleward current and the influence of subtropical sourced waters in the Bay of Biscay}

Modern surveys (e.g. Garcia-Soto et al., 2002; Lozier and Stewart, 2008; Garcia-Soto and Pingree, 2012) and palaeoceanographic time series (e.g. Mojtahid et al., 2013) recently evidenced the influence of the IPC, and its extension in the Bay of Biscay (i.e. Navidad Current; Garcia-Soto et al., 2002), on surface circulation and hydrological conditions along the European margin. At present, these incursions of warm waters in the bay occur during winter under specific seasonal wind regimes (of southerly wind off Portugal and westerly wind off northern Spain, Charria et al., 2013) and negative anomalies of sea level pressure over the North Atlantic (Pingree and Garcia-Soto, 2014). While these conditions were previously related to a negative mode of the NAO (Garcia-Soto et al., 2002), recent analysis of instrumental time series showed that weather conditions responsible for the Navidad Current may not always correspond to a fixed value of the NAO index (Pingree and Garcia-Soto, 2014). The Navidad Current occasionally creates warm SST anomalies, and enhanced transport of warm water through the pole, and could thus be the vector of planktonic exotic (from subtropical origin) faunal invasions in the inner Bay of Biscay (see Mojtahid et al., 2013, and Garcia et al., 2013, for example in the fossil record; see Garcia-Soto and Pingree, 2012, and Pingree and Garcia-Soto, 2014, for example in instrumental time series) which could bias our SST reconstructions. In the following, we thus examine the hypothesis of a persistent poleward surface current during the Holocene that would have triggered the observed SST warm anomalies in the PP10-07 and KS10b records.

In order to test the coherence of surface hydrographic features along the temperate and subtropical adjacent portions of the European margin, we compared Bay of Biscay SST reconstructions with existing SST (annual) records produced along the Iberian margin (Fig. 3b and c). We first test this link over historical times, compiling SST high-resolution data obtained on the proximal core MD03-2693 (after Mary et al., 2015), which accurately complete those from core PP10-07 (see Fig. 3a between 0.5 and $1.5 \mathrm{ka}$ and Fig. 5a', even if the cores are not tuned on each other, i.e. keeping their independent age models; see also Mary et al., 2015, and its supplement), with additional high-resolution records (Fig. 3b). The combination of these records reveals a slight warming associated with the Medieval Warm Period and coherent lowamplitude multi-decadal SST oscillations which echo those of AMO anomalies as reconstructed by Mann et al. (2009). Especially striking is the high degree of synchronicity detected between the Iberian margin (core PO287-06; Abrantes et al., 2011) and the Bay of Biscay at the scale of the 

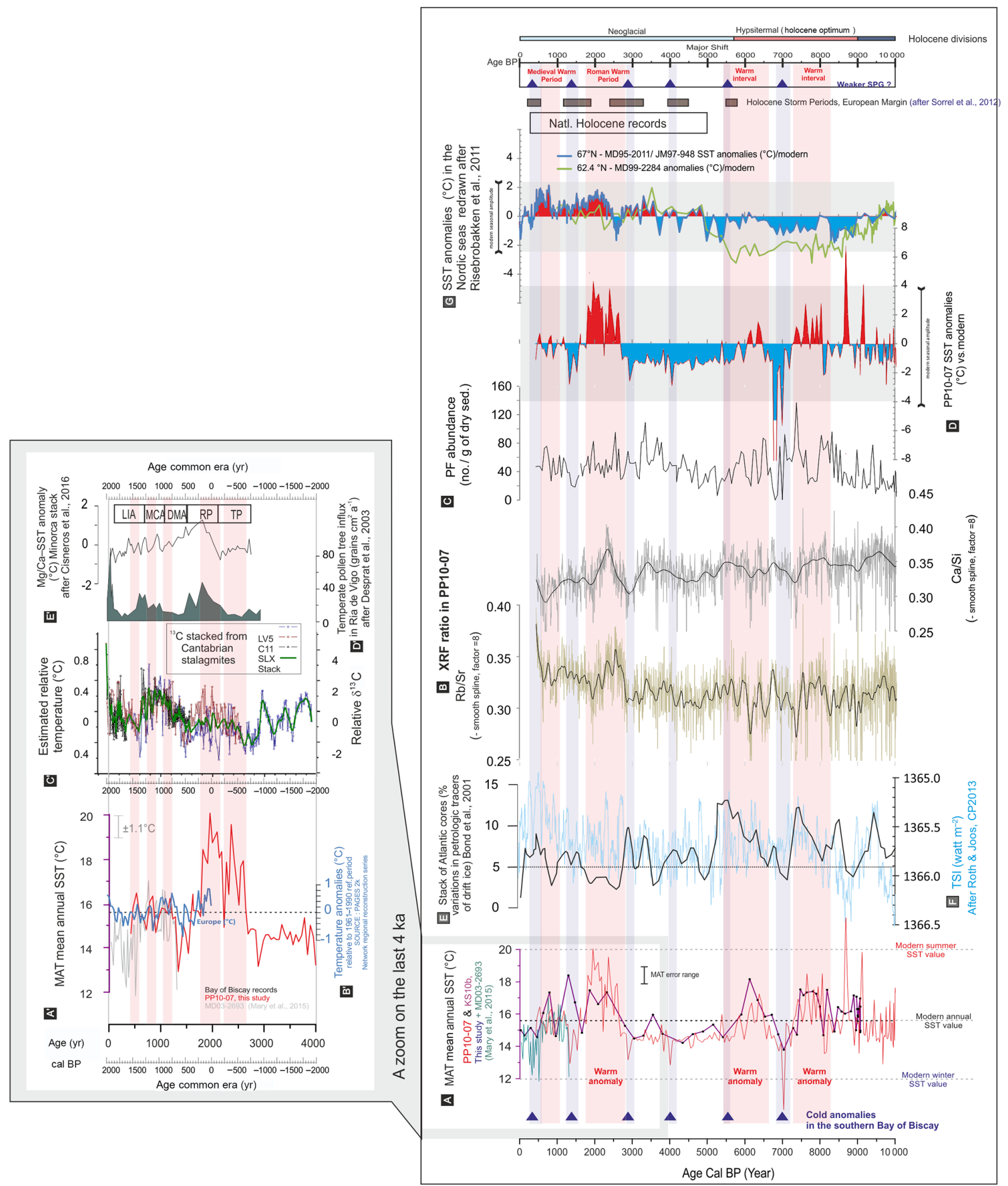

Figure 5. Gathering data and forcing: comparison of the Bay of Biscay (BB) signals (a annual SST, b XRF ratio in PP10-07, $\mathbf{c}$ planktonic foraminifera absolute abundances in PP10-07, $\mathbf{d}$ annual SST anomalies vs. modern mean in PP10-07), with key Holocene records, i.e. (e) Bond et al. (2001) record; (f) total solar irradiance reconstruction after Roth and Joos (2013); (g) annual SST anomalies in the Nordic seas (eastern) digitized from Risebrobakken et al. (2011, Fig. 3). The dark blue triangles and light blue vertical bands point to cold anomalies recorded in the BB (potentially corresponding to a weak SPG). On the left are compiled data from the last $4 \mathrm{kyr}$ with (a') BB annual SST; $\left(\mathbf{b}^{\prime}\right)$ reconstruction of the European temperature anomalies (from 30-year averages) of the PAGES 2k Network (2013); ( $\mathbf{c}^{\prime}$ ) Cantabrian speleothem $\delta^{13} \mathrm{C}$ stack reflecting $4 \mathrm{kyr}$ land surface temperature changes, digitized after Martín-Chivelet et al. (2011); (d' $\left.\mathbf{d}^{\prime}\right)$ temperate pollen tree influx from the proximal Ria de Vigo, redrawn after Desprat et al. (2003), (e') Mg / Ca SSt anomaly in Minorca and related historical events after Cisneros et al. (2016) (Talaiotic Period - TP; Roman Period - RP; "Dark Middle Ages" - DMA; Medieval Climate Anomaly MCA; Little Ice Age - LIA). 
last $1.5 \mathrm{kyr}$, despite differences in the proxies used to generate palaeo-SST (alkenones vs. MAT on PF respectively) and age-model uncertainties (which probably explain offsets of a few hundred years around AD 1200). The good coherence with AMO reconstructions further supports modern oceanographic assumptions of AMO driving multi-decadal change of SST in the area (Garcia-Soto and Pingree, 2012) and shows that this modulation is at least valid for the late Holocene. Interestingly, modern winter incursions of Iberian water through the Bay of Biscay take place during periods of increasing AMO (Garcia-Soto and Pingree, 2012). During these episodes, warm winter anomalies of up to $1.1^{\circ} \mathrm{C}$ are observed in the Bay of Biscay, which are consistent with the amplitude of the warmings detected in both MD03-2693 and PP10-07 past reconstructions.

However, over the longer Holocene perspective, existing SST records from the Iberian margin do not reveal any coherent patterns with those from the Bay of Biscay over the last $10 \mathrm{kyr}$ (Fig. 3c). Regardless of the proxies involved in SST reconstructions (alkenones and MAT), there is no evidence of any earlier distinct SST excursions in the high time resolution data of the Iberian cores MD99-2331, D13882, MD952042 and MD01-2444 (Fig. 3c; see also Fig. S4 in the Supplement) or elsewhere in other lower-resolution Holocene records from the same area (Naughton et al., 2007b; Martrat et al., 2007; Rodrigues et al., 2009; Voelker and de Abreu, 2011; Chabaud et al., 2014). The early Holocene SST reconstructions in this area show a monotonic long-term decrease of SST correlated with the Holocene decline of summer insolation (e.g. Marchal et al., 2002; see also Fig. S4) which contrasts strongly with the warm episodes observed in core PP10-07 and KS10b at that time (see Fig. S4 in the Supplement). Taking into account the similarities between late Holocene records in the Iberian margin and in the Bay of Biscay, our data thus suggest a disconnection between these two regions during the first part of the Holocene, up to $1.5 \mathrm{kyr}$ BP. We interpret this divergence as a distinct response of the Bay of Biscay to North Atlantic millennial changes in the NAC/SPF system dynamics (e.g. Pérez-Brunius et al., 2004) whereas southwestern Europe has probably undergone a mixed influence of diverse subtropical climatic trends. Seasurface environments from the Bay of Biscay, located at the interface between the SPG and STG influences may have, as currently observed in frontal regions, recorded an amplified signature of NAC shifts, themselves driven by contraction/extension phases of the whole North Atlantic gyre system (STP, SPG and polar gyre also). To decipher the role of each of these gyres is at present not possible on the basis of our records only, and requires additional high-resolution comparable marine archives along a latitudinal gradient at least between 30 and $60^{\circ} \mathrm{N}$. The analyses of the influence of Mediterranean hydrographic changes (via the Mediterranean outflow export especially) together with those linked to the eastern North Atlantic upwelling region would also be very important to tackle in such a context.

\section{Implication for Holocene climate dynamics}

In agreement with modern climate observations (e.g. Ba et al., 2014), North Atlantic palaeoceanographic studies describe a strong impact of the SPG dynamics on the NAC inflow toward high latitudes and global circulation during the Holocene (Bianchi and McCave, 1999; Oppo et al., 2003; Pérez-Brunius et al., 2004; Thornalley et al., 2009; Giraudeau et al., 2010; Moros et al., 2012; Staines-Urías, 2013; Morley et al., 2014). Freshwater fluxes in the Labrador Sea and wind stress over the North Atlantic are key drivers of eastern expansions/contractions of the SPG (Hatun et al., 2005), thus also controlling the salinity balance over the North Atlantic, boreal deep-water convection and Northern Hemisphere climate patterns. The compilation of proxy records from further south in the Bay of Biscay indicates that the Holocene relatively long-term periods of warming are interbedded/superposed to rapid, millennial cold anomalies of SPG origin (Fig. 4). In agreement with other North Atlantic records, strong NAC occurs preferentially during the Holocene optimum (Berner et al., 2008; Solignac et al., 2008), and during the Roman Warm Period (Werner et al., 2012). In contrast, the occurrences of cold anomalies in the North Atlantic follow a 1500-year periodicity during the Holocene (e.g. Thornalley et al., 2009; Debret et al., 2007; Sorrel et al., 2012), and are accurately reflected by the SST PP10-07 record (Fig. 4f).

As also suggested by recent studies of modern time series (Lozier et al., 2010; Lozier, 2012), Holocene SST records from the Bay of Biscay evidence a decoupling of gyre dynamics, and a potential gyre-specific expression of the AMOC. Model studies similarly question the meridional coherence of the AMOC, revealing an inherent character of its mid-latitude variability at decadal timescales (Bingham et al., 2007), mainly driven by wind forcing and eddy variability. While our findings support coherent sea-surface hydrographical patterns between subtropical and temperate environments along the western European margin, suggesting a coupled SPG/STG gyre dynamics over the last 1.5 to $2 \mathrm{kyr}$, earlier Holocene contexts seem to have been rather favourable to a gyre-specific expression, i.e. each gyre being related to intrinsic forcing mainly due to their latitudinal position and to proximal saline/fresh water intrusions.

To tentatively go further in the interpretations, we have compiled bibliographic sources dealing with the Holocene climatic variability. Many of the relevant records are considered in Figs. 4 and 5, with a close-up representation over the last $4 \mathrm{kyr}$ in Fig. $5 \mathrm{a}^{\prime}$ to $\mathrm{e}^{\prime}$ which gathers proximal European records. Related interpretations and elements regarding the SPG/STG (and other ocean and climate features when existing) were also compiled as a table (see Table S2 in the Supplement) to provide a comprehensive summary which is conceptualized in Fig. 6. With this exercise, it is confirmed that no definitive trend could be assessed over the whole Holocene. It seems rather that the delimitation of the 

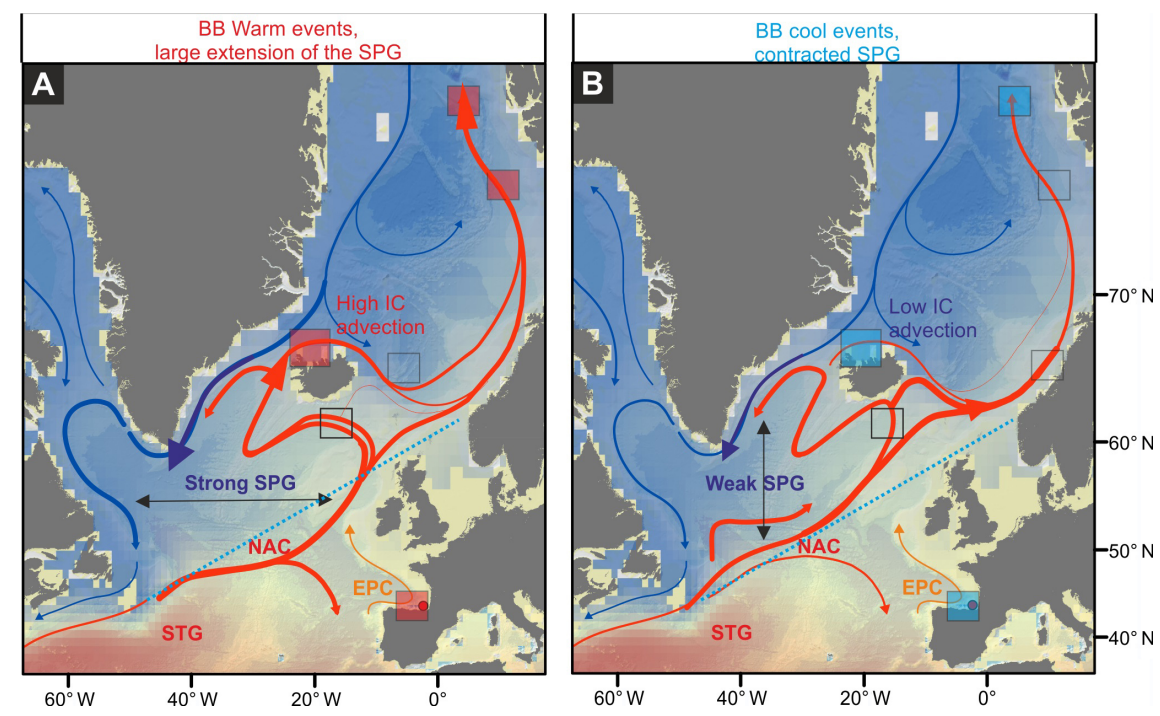

Figure 6. Tentative scheme of North Atlantic oceanic circulation changes associated to contrasted BB SST scenarios (a, BB warm anomalies; b, BB cool events). This figure, primarily based on Fig. 1b, was constructed compiling previous works of Staines-Urías et al. (2013) and of Morley et al. (2014) (see also Table S2). Squares identify the key records used in Figs. 4 and 5, with colours indicating warm/cool situation or empty when no clear trend is detectable.

mid-Holocene is of high relevance regarding the latitudinal coherence of climatic events. Probably in relation with the influence of relict ice-sheet melting (and thus fresh-water injection in the SPG) and the related sea-level rise stop, key connections and feedbacks may have taken place after $6 / 5 \mathrm{ka}$ only, thus triggering modern oceanographic and climatic modes. Actually, when focusing on the early Holocene, warm anomalies in the Bay of Biscay coincide with signals of significant NAC inflow in the GIN seas (Figs. 4 and 6a), but are not clearly seen on records from close to European ice sheets (Fig. 5e). At a millennial scale, these events seem to be in phase with evidences of solar activity changes (Fig. $5 \mathrm{f}$ - reverted scale) and important pulses of ice-drifting in the North Atlantic (after Bond et al., 2001, Fig. 5g). The centennial evolution within each event is however more complex. Over the last $5 \mathrm{kyr}$, trends seem to be more clearly expressed with, especially during the last millennia, good coherency at the local and regional scales (Fig. 5a' to $\mathrm{e}^{\prime}$ ). Warm/cold shifts occur in a well-defined temporal frame, relevant at least over Europe, but hardly attributable on the basis of our work to a preferential radiative forcing (internal as external).

To understand climatic processes behind these observations and test their coherency region per region, a pan(North)-Atlantic view is however required, emphasizing the need for comprehensive data compilation efforts as those undertaken for instance in the work conducted for the Ocean2k SST synthesis (e.g. McGregor et al., 2015) or the PAGES 2K Network consortium (http://pastglobalchanges. org/ini/wg/2k-network/intro). SST records should however be supplemented by complementary parameters when possible, especially to document hydrographic processes at var- ious depths, in order to better understand the 3-D articulation of the oceanic thermal and dynamic responses to various Holocene forcing (e.g. changes in insolation, sea-levelgateway connection, volcanism, or even anthropogenic related, which could have been cumulative or not).

\section{Conclusion}

Our study, which documents Holocene surface hydrographical changes at unprecedented timescales in the Bay of Biscay, reveals contrasted patterns (warm vs. cool SST) which correlate with other North Atlantic proxy records interpreted to be responding to North Atlantic gyre dynamics. Coherently with stronger NAC inflow in the Nordic seas as detected in other archives from the northern North Atlantic, our highresolution sedimentary records identify specific warm periods during the early Holocene and at ca. $2 \mathrm{kyr}$ BP and reveal that northward advection of subtropical waters may have influenced SST oscillations in the Bay of Biscay during the last $1.5 \mathrm{kyr}$ BP. In addition, SST signals from the Bay of Biscay show the occurrence of short-term cold anomalies, interpreted here as the signature of changes in SPG dynamics. The influence of the two main North Atlantic gyres, i.e STP vs. SPG, observed asynchronously over most of the Holocene in the Bay of Biscay, indicate fundamental differences in the temporal variability of their dynamics, contrasting with the idea of a coherent, basin-wide-driven, overturning cell in the North Atlantic. Our results suggest a gyre-specific expression of the AMOC where intrinsic salinity valves, linked to the latitudinal and geographical contexts, are of major importance. That may contribute to strong regionalisms in the 
response of the North Atlantic hydrography to Holocene climatic changes and point to the need to be as precise as possible when modelling this key component in the Earth climate system. This also urges for a densification (and maybe diversification) in the coverage of past Holocene archives.

Data availability. Data will be set on http://www.pangaea.de/ (doi:10.1594/PANGAEA.872166).

\section{The Supplement related to this article is available online at doi:10.5194/cp-13-201-2017-supplement.}

Author contributions. Yannick Mary and Frédérique Eynaud designed the study and wrote the paper in the frame of the ANR HAMOC project coordinated by Christophe Colin. Frédérique Eynaud, Linda Rossignol, Meryem Mojtahid, Jennifer Garcia, Marion Peral, and Hélène Howa performed and/or supervised planktonic foraminifera assemblage analyses and picking for the datings. Frédérique Eynaud ran the transfer function. Yannick Mary performed age modelling with the help of Frédérique Eynaud and Meryem Mojtahid. Sandra Brocheray, Sébastien Zaragosi and Michel Cremer investigated the sedimentology of core PP10-07. All authors contributed to discussions and interpretation of the results.

Competing interests. The authors declare that they have no conflict of interest.

Acknowledgements. Analyses documented in this study have been supported by the French ANR HAMOC. We are grateful to the captain and crew of the RV Pourquoi Pas? and to the scientific team of the 2010-SARGASS cruise. This work beneficiated from ${ }^{14} \mathrm{C}$ AMS measurement facilities thanks to the ARTEMIS French project. We thank Giovanni Sgubin, Didier Swingedouw and Eleanor Georgiadis for useful discussions and comments on the manuscript. This is an UMR EPOC contribution.

Edited by: T. Kiefer

Reviewed by: J. Scourse and one anonymous referee

\section{References}

Abrantes, F., Rodrigues, T., Montanari, B., Santos, C., Witt, L., Lopes, C., and Voelker, A. H. L.: Climate of the last millennium at the southern pole of the North Atlantic Oscillation: An innershelf sediment record of flooding and upwelling, Clim. Res., 48, 261-280, 2011.

Andrews, J. T. and Giraudeau, J.: Multi-proxy records showing significant Holocene environmental variability: the inner N. Iceland shelf (Hunafloi), Quaternary Sci. Rev., 22, 175-193, 2003.

Ba, J., Keenlyside, N. S., Latif, M., Park, W., Ding, H., Lohmann, K., Mignot, J., Menary, M., Otterå, O. H., Wouters, B., Salas y Melia, D., Oka, A., Bellucci, A., and Volodin, E.: A multi-model comparison of Atlantic multidecadal variability, Clim. Dynam., 43, 2333-2348, 2014.

Berner, K. S., Koç, N., Divine, D., Godtliebsen, F., and Moros, M.: A decadal-scale Holo-cene sea surface temperature record from the subpolar North Atlantic constructed using diatoms and statistics and its relation to other climate parameters, Paleoceanography, 23, PA2210, doi:10.1029/2006PA001339, 2008.

Bianchi, G. G. and McCave, I. N.: Holocene periodicity in North Atlantic climate and deep-ocean flow south of Iceland, Nature, 397, 515-517, 1999.

Bingham, R. J., Hughes, C. W., Roussenov, V., and Williams R. G.: Meridional coherence of the North Atlantic meridional overturning circulation, Geophys. Res. Lett., 34, L23606, doi:10.1029/2007GL031731, 2007.

Blaauw, M.: Methods and code for "classical" age-modelling of radiocarbon sequences, Quat. Geochronol., 5, 512-518, 2010.

Bond, G., Kromer, B., Beer, J., Muscheler, R., Evans, M. N., Showers, W., Hoffmann, S., Lotti-Bond, R., Hajdas, I., and Bonani, G.: Persistent solar influence on North Atlantic climate during the Holocene, Science, 294, 2130-2136, 2001.

Brocheray, S., Cremer, M., Zaragosi, S., Schmidt, S., Eynaud, F., Rossignol L., and Gillet, H.: 2000 years of frequent turbidite activity in the Capbreton Canyon (Bay of Biscay), Mar. Geol., 347, 136-152, doi:10.1016/j.margeo.2013.11.009, 2014.

Bryden, H. L., Longworth, H. R., and Cunningham, S. A.: Slowing of the Atlantic meridional overturning circulation at $25^{\circ} \mathrm{N}$, Nature, 438, 655-657, 2005.

Chabaud, L., Sanchez Goni, M. F., Desprat, S., and Rossignol, L.: Land-sea climatic variability in the eastern North Atlantic subtropical region over the last 14,200 years: Atmospheric and oceanic processes at different timescales, Holocene, 24, 787797, 2014.

Charria, G., Lazure, P., Le Cann, B., Serpette, A., Reverdin, G., Louazel, S., Batifoulier, F., Dumas, F., Pichon, A., and Morel, Y.: Surface layer circulation derived from Lagrangian drifters in the Bay of Biscay, J. Marine Syst., 109-110, S60-S76, doi:10.1016/j.jmarsys.2011.09.015, 2013.

Cisneros, M., Cacho, I., Frigola, J., Canals, M., Masqué, P., Martrat, B., Casado, M., Grimalt, J. O., Pena, L. D., Margaritelli, G., and Lirer, F.: Sea surface temperature variability in the central-western Mediterranean Sea during the last 2700 years: a multi-proxy and multi-record approach, Clim. Past, 12, 849-869, doi:10.5194/cp-12-849-2016, 2016.

Clark, P. U., Pisias, N. G., Stocker, T. F., and Weaver, A. J.: The role of the thermohaline circulation in abrupt climate change, Nature, 415, 863-869, 2002.

Copard, K., Colin, C., Henderson, G. M., Scholten, J., Douville, E., Sicre, M.-A., and Frank, N.: Late Holocene intermediate water variability in the northeastern Atlantic as recorded by deep-sea corals, Earth Planet. Sc. Lett., 313-314, 34-44, doi:10.1016/j.eps1.2011.09.047, 2012.

Colin, C., Frank, N., Copard, K., and Douville, E.: Neodymium isotopic composition of deep-sea corals from the NE Atlantic: implications for past hydrological changes during the Holocene, Quaternary Sci. Rev., 29, 2509-2517, doi:10.1016/j.quascirev.2010.05.012, 2010.

Dawson, A., Elliott, L., Noone, S., Hickey, K., Holt, T., Wadhams, P., and Foster, I.: Historical storminess and climate "see-saws" in the North Atlantic region, Mar. Geol., 210, 247-259, 2004. 
Debret, M., Bout-Roumazeilles, V., Grousset, F., Desmet, M., McManus, J. F., Massei, N., Sebag, D., Petit, J.-R., Copard, Y., and Trentesaux, A.: The origin of the 1500-year climate cycles in Holocene North-Atlantic records, Clim. Past, 3, 569-575, doi:10.5194/cp-3-569-2007, 2007.

deCastro, M., Gómez-Gesteira, M., Alvarez, I., and Gesteira, J. L. G.: Present warming within the context of cooling-warming cycles observed since 1854 in the Bay of Biscay, Cont. Shelf Res., 29, 1053-1059, doi:10.1016/j.csr.2008.11.016, 2009.

Desprat, S., Sánchez-Goñi, M. F., and Loutre, M.-F.: Revealing climatic variability of the last three millennia in northwestern Iberia using pollen influx data, Earth Planet. Sc. Lett., 213, 63-78, 2003.

Esnaola, G., Sáenz, J., Zorita, E., Fontán, A., Valencia, V., and Lazure, P.: Daily scale wintertime sea surface temperature and IPC-Navidad variability in the southern Bay of Biscay from 1981 to 2010, Ocean Sci., 9, 655-679, doi:10.5194/os-9-655-2013, 2013.

Eynaud, F., Turon, J. L., and Duprat, J.: Comparison of the Holocene and Eemian palaeoenvironments in the South Icelandic Basin: Dinoflagellate cysts as proxies for the North Atlantic surface circulation, Rev. Palaeobot. Palyno., 128, 55-79, 2004.

Eynaud, F., Rossignol, L., and Gasparotto, M.-C.: Planktic foraminifera throughout the Pleistocene: From cell to populations to past marine hydrology, Chap. 8, in: Foraminifera: Classification, Biology, and Evolutionary Significance, edited by: Georgescu, M. D., Nova Science Publishers, New York, NY, 2013.

Farmer, E. J., Chapman, M. R., and Andrews, J. E.: Holocene temperature evolution of the subpolar North Atlantic recorded in the $\mathrm{Mg} / \mathrm{Ca}$ ratios of surface and thermocline dwelling planktonic foraminifers, Global Planet. Change, 79, 234-243, 2011.

Garcia, J., Mojtahid, M., Howa, H., Michel, E., Schiebel, R., Charbonnier, C., Anschutz, P., and Jorissen, F. J.: Benthic and planktic foraminifera as indicators of late glacial to Holocene paleoclimatic changes in a marginal environment: An example from the southeastern Bay of Biscay, Acta Protozool., 52, 163-182, 2013.

Garcia-Soto, C. and Pingree, R. D.: Atlantic Multidecadal Oscillation (AMO) and sea surface temperature in the Bay of Biscay and adjacent regions, J. Mar. Biol. Assoc. UK, 92, 213-234, 2012.

Garcia-Soto, C., Pingree, R. D., and Valdés, L.: Navidad development in the southern Bay of Biscay: Climate change and swoddy structure from remote sensing and in situ measurements, J. Geophys. Res., 107, doi:10.1029/2001JC001012, 2002.

Gaudin, M., Mulder, T., Cirac, P., Berne, S., and Imbert, P.: Past and present sedimentation activity in the Capbreton Canyon, southern Bay of Biscay, Geo-Mar. Lett., 26, 331-345, 2006.

Giraudeau, J., Jennings, A. E., and Andrews, J. T.: Timing and mechanisms of surface and intermediate water circulation changes in the Nordic Seas over the last 10,000 cal years: a view from the North Iceland shelf, Quaternary Sci. Rev., 23, 21272139, 2004.

Giraudeau, J., Grelaud, M., Solignac, S., Andrews, J. T., Moros, M., and Jansen, E.: Millennial-scale variability in Atlantic water advection to the Nordic Seas derived from Holocene coccolith concentration records, Quaternary Sci. Rev., 29, 1276-1287, doi:10.1016/j.quascirev.2010.02.014, 2010.

Guiot, J. and de Vernal, A.: Transfer functions: Methods for quantitative paleoceanography based on microfossils, in: Proxies in
Late Cenozoic Paleoceanography, edited by: Hillaire-Marcel, C. and de Vernal, A., Amsterdam: Elsevier, 523-563, 2007.

Guiot, J. and de Vernal, A.: Is spatial autocorrelation introducing biases in the apparent accuracy of paleoclimatic reconstructions?, Quaternary Sci. Rev., 30, 1965-1972, 2011.

Hatun, H., Britt Sandø, A., Drange, H., Hansen, B., and Valdimarsson, H.: Influence of the Atlantic Subpolar Gyre on the Thermohaline Circulation, Science, 309, 1841-1844, 2005.

Hayes, A., Kucera, M., Kallel, N., Sbaffi, L., and Rohling, E. J.: Glacial Mediterranean sea surface temperatures based on planktonic foraminiferal assemblages, Quaternary Sci. Rev., 24, 999 1016, 2005.

Jackson, L. C., Kahana, R., Graham, T., Ringer, M. A., Woollings, T., Mecking, J. V., and Wood, R. A.: Global and European climate impacts of a slowdown of the AMOC in a high resolution GCM, Clim. Dynam., 45, 3299-3316, doi:10.1007/s00382-0152540-2, 2015.

Kennedy, J. J.: A review of uncertainty in in situ measurements and data sets of sea surface temperature, Rev. Geophys., 52, 1-32, doi:10.1002/2013RG000434, 2014.

Koutsikopoulos, C., Beillois, P., Leroy, C., and Taillefer, F.: Temporal trends and spatial structures of the sea surface temperature in the Bay of Biscay, Oceanol. Acta, 21, 335-344, 1998.

Kucera, M., Weinelt, M., Kiefer, T., Pflaumann, U., Hayes, A., Weinelt, M., Chen, M.-T., Mix, A.-C., Barrows, T. T., Cortijo, E., Duprat, J., Juggins, S., and Waelbroeck, C.: Reconstruction of sea-surface temperatures from assemblages of planktonic foraminifera: multi-technique approach based on geographically constrained calibration data sets and its application to glacial Atlantic and Pacific Oceans, Quaternary Sci. Rev., 24, 951-998, doi:10.1016/j.quascirev.2004.07.014, 2005.

Landsea, C. W., Vecchi, G. A., Bengtsson, L., and Knutson, T. R.: Impact of Duration Thresholds on Atlantic Tropical Cyclone Counts*, J. Climate, 23, 2508-2519, 2010.

Le Cann, B. and Serpette, A.: Intense warm and saline upper ocean inflow in the southern Bay of Biscay in autumn-winter 2006-2007, Cont. Shelf Res., 29, 1014-1025, doi:10.1016/j.csr.2008.11.015, 2009.

Lherminier, P. and Thierry, V.: The Reykjanes Ridge Experiment, http://wwz.ifremer.fr (last access: 22 November 2016), 2015.

Lozier, M. S.: Overturning in the North Atlantic, Annual Review of Marine Science, 4, 291-315, 2012.

Lozier, M. S. and Stewart, N. M.: On the Temporally Varying Northward Penetration of Mediterranean Overflow Water and Eastward Penetration of Labrador Sea Water, J. Phys. Oceanogr., 38, 2097-2103, 2008.

Lozier, M. S., Roussenov, V., Reed, M. S. C., and Williams, R. G.: Opposing decadal changes for the North Atlantic meridional overturning circulation, Nat. Geosci., 3, 728-734, 2010.

Magny, M., Bégeot, C., Guiot, J., and Peyron, O.: Contrasting patterns of hydrological changes in Europe in response to Holocene climate cooling phases, Quaternary Sci. Rev., 22, 1589-1596, 2003.

Mann, M. E., Zhang, Z., Rutherford, S., Bradley, R. S., Hughes, M. K., Shindell, D., Ammann, C. Faluvegi, G., and Ni, F.: Global signatures and dynamical origins of the Little Ice Age and Medieval Climate Anomaly, Science, 326, 1256-1260, 2009 (data available at: http://www.meteo.psu.edu/holocene/public_ html/supplements/MultiproxySpatial09/, last access: July 2016). 
Marchal, O., Cacho, I., Stocker, T. F., Grimalt, J. O., Calvo, E., Martrat, B., Shackleton, N., Vautravers, M., Cortijo, E., and van Kreveld S.: Apparent long-term cooling of the sea surface in the northeast Atlantic and Mediterranean during the Holocene, Quaternary Sci. Rev., 21, 455-483, 2002.

Martín-Chivelet, J., Muñoz-García, M. B., Edwards, R. L., Turrero, M. J., and Ortega, A. I.: Land surface temperature changes in Northern Iberia since $4000 \mathrm{yr} \mathrm{BP}$, based on $\delta^{13} \mathrm{C}$ of speleothems, Global Planet. Change, 77, 1-12, 2011.

Martrat, B., Grimalt, J. O., Shackleton, N. J., de Abreu, L., Hutterli, M. A., and Stocker, T. F.: Four Climate Cycles of Recurring Deep and Surface Water Destabilizations on the Iberian Margin, Science, 317, 502-507, 2007 (data available at: doi:10.1594/PANGAEA.771894).

Mary, Y., Eynaud, F., Zaragosi, S., Malaizé, B., Cremer, M., and Schmidt, S.: High frequency environmental changes and deposition processes in a $2 \mathrm{kyr}-$ long sedimentological record from the Cap-Breton canyon (Bay of Biscay), Holocene, 25, 348-365, doi:10.1177/0959683614558647, 2015.

Mary, Y., Eynaud, F., Colin, C., Rossignol, L., Brocheray, S., Mojtahid, M., Garcia, J., Peral, M., Howa, H., Zaragosi, S., and Cremer, M.: Interactive comment on "Changes in Holocene meridional circulation and poleward Atlantic flow: the Bay of Biscay as a nodal point" by Yannick Mary et al., Clim. Past. Discuss., doi:10.5194/cp-2016-32-AC2, 2016.

McCartney, M. S. and Mauritzen, C.: On the origin of the warm inflow to the Nordic Seas, Prog. Oceanogr., 51, 125-214, 2001.

McGregor, H. V., Evans, M. N., Goosse, H., Leduc, G., Martrat, B., Addison, J. A., Mortyn, P. G., Oppo, D. W., Seidenkrantz, M.-S., Sicre, M.-A., Phipps, S. J., Selvaraj, K., Thirumalai, K., Filipsson, H. L., and Ersek, V.: Robust global ocean cooling trend for the pre-industrial Common Era, Nat. Geosci., 8, 671-677, doi:10.1038/ngeo2510, 2015.

Mojtahid, M., Jorissen, F. J., Garcia, J., Schiebel, R., Michel, E., Eynaud, F., Gillet, H., Cremer, M., Diz Ferreiro, P., Siccha, M., and Howa, H.: High resolution Holocene record in the southeastern Bay of Biscay: Global versus regional climate signals, Palaeogeogr. Palaeocl., 377, 28-44, doi:10.1016/j.palaeo.2013.03.004, 2013.

Morley, A., Rosenthal, Y., and deMenocal, P.: Ocean-atmosphere climate shift during the mid-to-late Holocene transition, Earth Planet. Sc. Lett., 388, 18-26, doi:10.1016/j.eps1.2013.11.039, 2014.

Moros, M., Jansen, E., Oppo, D. W., Giraudeau, J., and Kuijpers, A.: Reconstruction of the late-Holocene changes in the Sub-Arctic Front position at the Reykjanes Ridge, north Atlantic, Holocene, 22, 877-868, 2012.

Naughton, F., Bourillet, J. F., Sanchez Goni, M.-F., Turon J.-L., and Jouanneau J.-M.: Long-term and millennial-scale climate variability in northwestern France during the last 8850 years, Holocene, 17, 939-953, 2007a.

Naughton, F., Sanchez Goñi, M. F., Desprat, S., Turon, J.-L., Duprat, J., Malaizé, B., Joli, C., Cortijo, E., Drago, T., and Freitas, M. C.: Present-day and past (last 25000 years) marine pollen signal off western Iberia, Mar. Micropaleontol., 62, 91114, doi:10.1016/j.marmicro.2006.07.006, 2007b.

Ollitrault, M. and Colin de Verdière, A.: The ocean general circulation near 1000 m depth, J. Phys. Oceanogr., 44, 384-409, 2014.
Oppo, D. W., McManus, J. F., and Cullen, J. L.: Deepwater variability in the Holocene epoch, Nature, 422, 277-278, 2003.

Peliz, Á., Dubert, J., Santos, A. M. P., Oliveira, P. B., and Le Cann, B.: Winter upper ocean circulation in the Western Iberian Basin Fronts, Eddies and Poleward Flows: an overview, Deep-Sea Res. Pt. I, 52, 621-646, doi:10.1016/j.dsr.2004.11.005, 2005.

Pena, L. D., Francés, G., Diz, P., Esparza, M., Grimalt, J. O., Nombela, M. A., and Alejo, I.: Climate fluctuations during the Holocene in NW Iberia: High and low latitude linkages, Cont. Shelf Res., 30, 1487-1496, doi:10.1016/j.csr.2010.05.009, 2010.

Penaud, A., Eynaud, F., Sánchez-Goñi, M. F., Malaizé, B., Turon, J. L., and Rossignol, L.: Contrasting sea-surface responses between the western Mediterranean Sea and eastern subtropical latitudes of the North Atlantic during abrupt climatic events of MIS 3, Mar. Micropaleontol., 80, 1-17, 2011.

Pérez-Brunius, P., Rossby, T., and Watts, D. R.: Absolute transports of mass and temperature for the North Atlantic Current-Subpolar Front system, J. Phys. Oceanogr., 34, 1870-1883, 2004.

Pflaumann, U., Duprat, J., Pujol, C., and Labeyrie, L. D.: SIMMAX: A modern analog technique to deduce Atlantic sea surface temperatures from planktonic foraminifera is deep-sea sediments, Paleoceanography, 11, 15-35, 1996.

Pingree, R.: North Atlantic and North Sea climate change: curl up, shut down, NAO and ocean colour, J. Mar. Biol. Assoc. UK, 85, 1301-1315, 2005.

Pingree, R. D. and Garcia-Soto, C.: Plankton blooms, ocean circulation and the European slope current: Response to weather and climate in the Bay of Biscay and W English Channel (NE Atlantic), Deep-Sea Res. Pt. II, 106, 5-22, 2014.

Pingree, R. D. and Le Cann, B.: Structure, strength and seasonality of the slope currents in the Bay of Biscay region, J. Mar. Biol. Assoc. UK, 70, 857-885, 1990.

Planque, B., Beillois, P., Jégou, A.-M., Lazure, P., Petitgas, P., and Puillat, I.: Large-scale hydroclimatic variability in the Bay of Biscay: the 1990s in the context of interdecadal changes, in: ICES Marine Science Symposia, 219, 61-70, 2003.

Reimer, P. J., Bard, E., Bayliss, A., Beck, J. W., Blackwell, P. G., Ramsey, C. B., Buck, C. E., Cheng, H., Edwards, R. L., Friedrich, M., Grootes, P. M., Guilderson, T. P., Haflidason, H., Hajdas, I., Hatté, C., Heaton, T. J., Hoffmann, D. L., Hogg, A. G., Hughen, K. A., Kaiser, K. F., Kromer, B., Manning, S. W., Niu, M., Reimer, R. W., Richards, D. A., Scott, E. M., Southon, J. R., Staff, R. A., Turney, C. S. M., and van der Plicht, J.: IntCal13 and Marine13 Radiocarbon Age Calibration Curves 0-50,000 Years cal BP, Radiocarbon, 55, 1869-1887, doi:10.2458/azu_js_rc.55.16947, 2013.

Retailleau, S., Howa, H., Schiebel, R., Lombard, F., Eynaud, F., Schmidt, S., Jorissen, F., and Labeyrie, L.: Planktic foraminiferal production along an offshore-onshore transect in the southeastern Bay of Biscay, Cont. Shelf Res., 29, 1123-1135, 2009.

Retailleau, S., Eynaud, F., Mary, Y., Schiebel, R., and Howa, H.: An Ocean - Canyon head and river plume: how they may influence neritic planktonic foraminifera communities in the SE Bay of Biscay?, J. Foramin. Res., 42, 257-269, 2012.

Risebrobakken, B., Dokken, T., Smedsrud, L. H., Andersson, C., Jansen, E., Moros, M., and Ivanova, E. V.: Early Holocene temperature variability in the Nordic Seas: The role of oceanic heat advection versus changes in orbital forcing, Paleoceanography, 26, PA4206, doi:10.1029/2011PA002117, 2011. 
Rodrigues, T., Grimalt, J. O., Abrantes, F. G., Flores, J. A., and Lebreiro, S. M.: Holocene interdependences of changes in sea surface temperature, productivity, and fluvial inputs in the Iberian continental shelf (Tagus mud patch), Geochem. Geophy. Geosys., 10, Q07U06, doi:10.1029/2008GC002367, 2009 (data available at: doi:10.1594/PANGAEA.761812).

Roth, R. and Joos, F.: A reconstruction of radiocarbon production and total solar irradiance from the Holocene ${ }^{14} \mathrm{C}$ and $\mathrm{CO}_{2}$ records: implications of data and model uncertainties, Clim. Past, 9, 1879-1909, doi:10.5194/cp-9-1879-2013, 2013.

Salgueiro, E., Voelker, A., Abrantes, F., Meggers, H., Pflaumann, U., Loncaric, N., Gonzalez-Ãlvarez, R., Oliveira, P., Bartels-Jónsdóttir, H. B., Moreno, J., and Wefer, G.: Planktonic foraminifera from modern sediments reflect upwelling patterns off Iberia: Insights from a regional transfer function, Mar. Micropaleontol., 66, 135-164, 2008.

Salgueiro, E., Voelker, A. H. L., de Abreu, L., Abrantes, F., Meggers, H., and Wefer, G.: Temperature and productivity changes off the western Iberian margin during the last $150 \hat{\mathrm{A}} \mathrm{ky}$, Quaternary Sci. Rev., 29, 680-695, 2010.

Sánchez Goñi, M. F., Bakker, P., Desprat, S., Carlson, A. E., Van Meerbeeck, C. J., Peyron, O., Naughton, F., Fletcher, W. J., Eynaud, F., Rossignol, L., and Renssen, H.: European climate optimum and enhanced Greenland melt during the Last Interglacial, Geology, 40, 627-630, 2012.

Sánchez Goñi, M. F., Bard, E., Landais, A., Rossignol, L., and d'Errico, F.: Air-sea temperature decoupling in western Europe during the last interglacial-glacial transition, Nat. Geosci., 6, 837-841, doi:10.1038/ngeo1924, 2013.

Sarnthein, M., Van Kreveld, S., Erlenkeuser, H., Grootes, P. M., Kucera, M., Pflaumann, U., and Schulz, M.: Centennial-tomillennial-scale periodicities of Holocene climate and sediment injections off the western Barents shelf, $75^{\circ} \mathrm{N}$, Boreas, 32, 447461, 2003.

Schäfer-Neth, C. and Manschke, A.: WOA-Sample tool, http: //www.geo.uni-bremen.de/geomod/staff/csn/woasample.html (last access: January 2016), 2002.

Solignac, S., Grelaud, M., de Vernal, A., Giraudeau, J., Moros, M., McCave, N., and Hoogakker, B.: Reorganization of the upper ocean circulation in the mid-Holocene in the Northeastern Atlantic, Can. J. Earth Sci., 45, 1417-1433, 2008.

Sorrel, P., Tessier, B., Demory, F., Delsinne, N., and Mouazé, D.: Evidence for millennial-scale climatic events in the sedimentary infilling of a macrotidal estuarine system, Quaternary Sci. Rev., 28, 499-516, 2009.

Sorrel, P., Debret, M., Billeaud, I., Jaccard, S. L., McManus, J. F., and Tessier, B.: Persistent non-solar forcing of Holocene storm dynamics in coastal sedimentary archives, Nat. Geosci., 12, 892896, doi:10.1038/ngeo1619, 2012.

Staines-Urías, F., Kuijpers, A., and Korte, C.: Evolution of subpolar North Atlantic surface circulation since the early Holocene inferred from planktic foraminifera faunal and stable isotope records, Quaternary Sci. Rev., 76, 66-81, 2013.

Tanner, B. R., Lane, C. S., Martin, E. M., Young, R., and Collins, B.: Sedimentary proxy evidence of a mid-Holocene hypsithermal event in the location of a current warming hole, North Carolina, USA, Quaternary Res., 83, 315-323, doi:10.1016/j.yqres.2014.11.004, 2015.
Telford, R. J. and Birks, H. J. B.: Effect of uneven sampling along an environmental gradient on transfer-function performance, J. Paleolimnol., 46, 99-106, 2011.

Telford, R. J., Li, C., and Kucera, M.: Mismatch between the depth habitat of planktonic foraminifera and the calibration depth of SST transfer functions may bias reconstructions, Clim. Past, 9, 859-870, doi:10.5194/cp-9-859-2013, 2013.

Thornalley, D. J. R., Elderfield, H., and McCave, I. N.: Holocene oscillations in temperature and salinity of the surface subpolar North Atlantic, Nature, 457, 711-714, 2009.

Trouet, V., Scourse, J. D., and Raible, C. C.: North Atlantic storminess and Atlantic Meridional Overturning Circulation during the last Millennium: Reconciling contradictory proxy records of NAO variability, Global Planet. Change, 84-85, 48-55, 2012.

Valencia, V., Borja, Å., Fontån, A., Pérez, F. F., and Rios, A. F.: Temperature and salinity fluctuations along the Basque Coast (southeastern Bay of Biscay), from 1986 to 2000, related to climatic factors, ICES J. Mar. Sci., 219, 340-342, 2003.

Van Vliet-Lanoe, B., Goslin, J., Hallegouet, B., Henaff, A., Delacourt, C., Fernane, A., Franzetti, M., Le Cornec, E., Le Roy, P., and Penaud, A.: Middle- to late-Holocene storminess in Brittany (NW France): Part I - morphological impact and stratigraphical record, Holocene, 24, 413-433, doi:10.1177/0959683613519687, 2014a.

Van Vliet-Lanoe, B., Penaud, A., Henaff, A., Delacourt, C., Fernane, A., Goslin, J., Hallegouet, B., and Le Cornec, E.: Middleto late-Holocene storminess in Brittany (NW France): Part II The chronology of events and climate forcing, Holocene, 24, 434-453, doi:10.1177/0959683613519688, 2014b.

Voelker, A. H. L. and de Abreu, L.: A Review of Abrupt Climate Change Events in the Northeastern Atlantic Ocean (Iberian Margin): Latitudinal, Longitudinal, and Vertical Gradients, in: Geophysical Monograph Series, edited by: Rashid, H., Polyak, L., and Mosley-Thompson, E., American Geophysical Union, Washington, D.C., 15-37, 2011.

Walker, M. J. C., Berkelhammer, M., Björck, S., Cwynar, L. C., Fisher, D. A., Long, A. J., Lowe, J. J., Newnham, R. M., Rasmussen S. O., and Weiss, H.: Formal subdivision of the Holocene Series/Epoch: a Discussion Paper by a Working Group of INTIMATE (Integration of ice-core, marine and terrestrial records) and the Subcommission on Quaternary Stratigraphy (International Commission on Stratigraphy), J. Quaternary Sci., 27, 649659, 2012.

Wanner, H., Beer, J., Bütikofer, J., Crowley, T. J., Cubasch, U., Flückiger, J., Goosse, H., Grosjean, M., Joos, F., Kaplan, J. O., Küttel, M., Müller, S. A., Prentice, I. C., Solomina, O., Stocker, T. F., Tarasov, P., Wagner, M., and Widmann, M.: Mid- to Late Holocene climate change: an overview, Quaternary Sci. Rev., 27, 1791-1828, doi:10.1016/j.quascirev.2008.06.013, 2008.

Werner, K., Spielhagen, R. F., Bauch, D., Hass, H. C., and Kandiano, E. S.: Atlantic Water advection versus sea-ice advances in the eastern Fram Strait during the last 9 ka: Multiproxy evidence for a two-phase Holocene, Paleoceanography, 28, 283-295, 2013 (data available at: doi:10.1594/PANGAEA.810415). 